\title{
AGILE APPROACH VERSUS CLASSICAL APPROACH IN PROJECT MANAGEMENT WITH REGARD TO LEADERSHIP CHANGE
}

\section{Nurgul Janowski ${ }^{1}$}

Faculty of Business, Management and Economics, University of Latvia, Riga, Latvia

\begin{abstract}
Agility is a term which is modern and present nowadays in all levels and areas of companies. The increasingly changing situation on the market and the fundamental uncertainty forces companies to be more flexible and this flexibility cannot be covered only by classical existing approach. Therefore, this article results from the need to introduce a new approach and to compare it with the existing classical approach.

This article gives a definition for agility, discusses different scientific theories about agility and describes why agile approach is necessary in companies and where the differences between the previous classic approach and the agile approach is. The change has to be supported by leadership and for this reason in this article are introduced leadership types that support the agile change in the company.
\end{abstract}

Keywords: agility, leadership, change, classic approach, project management, comparison

\section{Introduction}

The world is getting faster, and more complex and traditional practices can no longer compete in companies. Shifting economic forces, accelerated urbanisation, technological breakthroughs therefore present today's companies with unprecedented challenges.

The increasing speed at which markets, products, technologies and subsequently also business models change, means that a company's ability to change becomes a critical success factor. A constantly changing market situation and the accompanying trend towards digitalization demand companies a high degree of flexibility to continuously adapt and optimise their strategy and its implementation.

1 Contact: Nurgul Janowski; nurgul.janowski@gmx.de; University of Latvia, Kunigundenstr. 28, Munich, 80802, Germany. 
When it comes to becoming a more agile company, it is above all company leaders that are crucial. A leader needs a lot of courage and foresight to start a change early enough. A change that questions the existing classical approach and deals with new business models based on agility and thus to remain successful in the medium and long term.

Leadership is a very important part for agility in companies and plays the main role in its implementation and cares also for the sustainability. In addition, leadership means not only limiting oneself to the methodological and business topics, but initiating the necessary cultural change with a changed mindset and being open to the challenges that arise.

Traditional organisations are not designed for the dynamic development of the changing economy today. The following study shows the direct connection between agility and success: agile companies achieve aboveaverage margins up to five times more often and grow faster than their competitors. Over $40 \%$ of all agile companies are top performers, only $24 \%$ develop below average. In the case of rather sluggish organisations, on the other hand, the risk of being at the bottom is increased: more than half of the rigid organisations develop below average. Only $18 \%$ of them are above average success ${ }^{2}$.

The purpose of this article is to give a definition of agility, to introduce different theories about agility and related leadership, as well as to do a comparison between the agile approach and the classical approach. In the comparison will be considered the changing role of the leadership.

\section{Definition of Agility}

Agility became popular in the early 1990s through publications on production strategies in the $21^{\text {st }}$ century ${ }^{3}$. The popularity of agility in the decade increased primarily due to its use in $\mathrm{IT}^{4}$. What has been new since the beginning of the 2000s is the bundling of different methods within frameworks ${ }^{5}$.

${ }^{2}$ Roghé F., Scholz S., Schudey A.: Organisation im 21. Jahrhundert. Eine Studie identifiziert sechs Erfolgsfaktoren. Zeitschrift Führung und Organisation. www.wisonet.de. 04/2017 (86. Jg.) p. 244-249.

${ }^{3}$ Förster, K., \& Wendler, R.: Theorien und Konzepte zu Agilität in Organisationen. Dresdner Beiträge zur Wirtschaftsinformatik, 63(12), 1, 2012.

${ }^{4}$ Mergel, I.: Agile Innovation management in government: A research agenda. Government Information Quarterly, 33(3), 2016, p. 518.

${ }^{5}$ Williams, L., \& Cockburn, A.: Agile Software Development: It's about Feedback and Change. Computer, 36(6), 39-43, 2003, p. 40. 
According to Highsmith the term "agile" is intended to express the idea that the management and steering of projects and processes must be dynamic and flexible and that it must also be possible to implement requirements and react to changes in turbulent and rapidly changing market conditions 6 .

According to Termer and Nissen, movement in the context of agility means that a person's position in relation to his or her environment changes over time. Agility means creating this flexibility out of one's own drive, usually even before a situation or an event makes this mobility necessary ${ }^{7}$. Agility requires a high level of communication in a network of individuals. For this reason, Appelo also attributes a high degree of networking and flexibility and trust are based on the relationship and communication between individuals.

Agility requires a high level of communication in a network of individuals. For this reason, Appelo also attributes a high degree of networking and flexibility and trust are based on the relationship and communication between individuals ${ }^{8}$.

Short, iterative development cycles should create added value for customers. The implementation is self-organised, which is also described as the core of agility ${ }^{9}$. Agility requires a constant speed of work and the proactive integration of the customer into the development process in order to react quickly to changing framework conditions ${ }^{10}$.

Teams work synchronously on a common goal and achieve its sub-goals through incremental product deliveries. Agility requires a high degree of team discipline which is driven indirectly by team members ${ }^{11}$.

Agility is also described as "radical employee orientation"12. Some elements (customer loyalty) are not a new phenomenon, but rather

${ }^{6}$ Highsmith, J. A.: Agile project management; creating innovative products; 1 . Auflage; Addison-Wesley Longman; Amsterdam; 2004; p. 16.

${ }^{7}$ Termer F., Nissen V.: Zum Begriff der Agilität - Betrachtungen und Implikation ausetymologischer Perspektive, 2014.

${ }^{8}$ Williams, L., \& Cockburn, A.: Agile Software Development: It's about Feedback and Change. Computer, 36(6), 39-43, 2003.

${ }^{9}$ Förster, K., \& Wendler, R.: Theorien und Konzepte zu Agilität in Organisationen. Dresdner Beiträge zur Wirtschaftsinformatik, 63(12), 1, 2012, p. 20.

${ }^{10}$ Dingsøyr, T., \& Lassenius, C.: Emerging themes in agile software development: Introduction to the special section on continuous value delivery. Information and Software Technology, 2012, p. 1214.

${ }^{11}$ Siakas, K. V., \& Siakas, R.: The Agile Professional Culture: A Source of Agile Quality. Software Process Improvement and Practice, 12, 2012, p. 607.

${ }^{12}$ Häusling, A., Rutz, B., Oimann, K., \& Oebbeke, B.: Agil anpassen! Personalmagazin, 2014, p. 18. 
an evolution of best practices that have been continually adapted and improved ${ }^{13}$. The previous focus on automation and standardisation increases the effectiveness of an organisation, but prevents innovations that are not guided by machines in the form ${ }^{14}$.

The paradox in the classic way of thinking is the natural, inherent uncertainty in processes, which cannot be compensated by even more advance planning. Robust planning necessary for this is only possible if all knowledge is available in advance. However, this does not correspond to reality.

It is clear to note that the definition is not yet clear, and one cannot yet say what is agile. It is also unclear which framework for agility really fits the definition of agile companies ${ }^{15}$.

The foundation is therefore the four agile values and 12 agile principles of the agile manifesto. The Agile Manifesto was written by 17 software developers. In addition, there are agile methods that primarily come from software development, but are increasingly being used as a management method, such as Scrum ${ }^{16}$. Rigby, Sutherland and Takeuchi state, almost 20 years after the Agile Manifesto, that agility has brought about a revolutionary change in software development ${ }^{17}$.

The continuous expansion within IT, as well as in other industrial sectors demonstrates the interest in shortened reaction times. This requires the adaptation of agile methods to the new requirements. This is increasingly leading to a growing acceptance of agility as a management concept.

From the application level agile principles are transferred for example to the development and production of physical parts in automotive engineering ${ }^{18}$. Besides product development, agile processes can also be implemented in sales, marketing, strategic planning, and logistics. Less

${ }^{13}$ Miller, G. G.: TOOLS '01 Proceedings of the $39^{\text {th }}$ International Conference and Exhibition on Technology of Object-Oriented Languages and Systems: The Characteristics of Agile Software Processes (pp. 385-387). Washington, DC, 2001, p. 387.

${ }^{14}$ Stoffel, M. 2016: Leadership 4.0 - Unternehmen brauchen ein neues "Betriebssystem". In von C. Au (Ed.), Wirksame und nachhaltige Führungsansätze (pp. 205-222), Wiesbaden: Springer.

${ }^{15}$ Förster, K., \& Wendler, R.: Theorien und Konzepte zu Agilität in Organisationen. Dresdner Beiträge zur Wirtschaftsinformatik, 2012, p. 7.

${ }^{16}$ Alegría and Bastarrica (2006, pp. 5-10); Häusling and Wiegand (2012, p. 19) Häusling, A., \& Wiegand, S. (2012). Agil dank Scrum. Personalmagazin, 06, 18-20.

${ }^{17}$ Rigby, D. K., Sutherland, J., \& Takeuchi, H. (2016). Embracing Agile. Harvard Business Review.

${ }^{18}$ Erretkamps, H., \& Oswald, A.: Der agile Produktentstehungsprozess - mehr als ein Prozess. In R. Wagner, \& N. Grau (Eds.), Basiswissen Projektmanagement - Prozesse und Vorgehensmodelle, Düsseldorf: Sypmposion, 2014, pp. 1-31. 
obvious is the use of agile processes in plant maintenance, sales and controlling. ${ }^{19}$

The following illustration (Figure 1) shows the order of the terms "Agile Value", "Agile Principal" and "Agile Method". It is important to notice that by starting with agile values, from invisible to the visible level and work with agile methods like Scrum, one of the agile methods. But to work effective in agile content it is needed to internalise the agile values and principles.

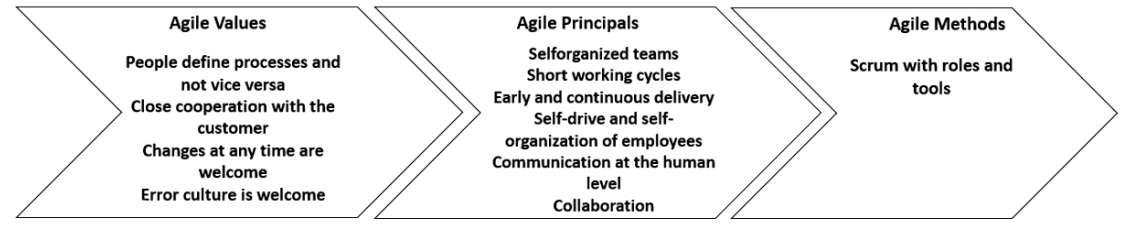

Figure 1. Agile scaling based on the existing characteristics in companies Source: Author's illustration

In summary it can be said that agility originates from the digital world and is understood in between as a cross-industry solution approach for a VUCA (V-volatility, U-uncertainty, C-complexity, A-ambiguity) environment. By transferring it to other application areas, agility has established itself as a management concept with a basic strategic understanding.

Agile companies work with a state that is both stable and flexible. Stability is created by frameworks for agile leadership, organisation, strategic goal setting and work. These enable the systematic, flexible handling of dynamic external requirements. Maximum adaptability with optimal stability is the declared maximum goal of agile enterprises.

Agility is not an end in itself - rather, it is about interacting more flexibly and at shorter intervals with the complex company environment. This interaction ultimately leads to better services and products for customers, and thus to market-changing offers. Rather, agility should increase the adaptability of the company and increase internal effectiveness and efficiency. Ideally, this is achieved by working agile and according to agile methods at all levels of the company.

\section{Agile approach versus classical approach}

Due to globalisation and internationalisation, the companies are facing pressures to be competitive in the market. The companies started to engage

${ }^{19}$ Rigby, D. K., Sutherland, J., \& Takeuchi, H.: Embracing Agile [Supplemental material]. Harvard Business Review. Retrieved from https://hbr.org/2016/05/embracing-agile, 2016. 
in project-based activities to solve this problem by reducing the uncertainty and to deliver product on time to the market ${ }^{20}$.This concept, in the context of an organisation, will allow to increase the flexibility, velocity, leanness, learning and response to change ${ }^{21}$.

Projects are formed to solve tasks that can be processed within the line. These are usually tasks that have to be processed only once or only rarely. When planning a project, the goals and the necessary resources are defined, and it is also crucial to create the framework conditions for the project organisation and the corresponding processes. Before a project can be started, the setting of objectives should be clear and the task should be defined, naturally adapted to the market requirements and the environment. Project management has the focus to follow the accomplishment of plans. The important and the main way is based on what is done on time and within budget. For this reason, tracing project plan is also the main task of project management.

According to Moran, agile project management is defines as "discipline that copes adaptively with rapid change through feedback learning loops that iteratively create and incrementally deliver value" 22 .

Agile project management approaches are becoming more common and popular in projects ${ }^{23}$, but it is not enterprise goal to reorganise the organisational structure. For this reason, there are existing hierarchical organisational structures und agile project structure side by side ${ }^{24}$. This leads to difficulties, as the structures strive for control and obedience rather than networking and communication. The challenge is to continue to promote agile projects despite the existing organisational structures and to bring them to a successful conclusion. The agile values and principles provide the framework for agile working. But they do not yet help to set up a concrete project management.

The continues improvement process is an important aspect. Because agility is a characteristic for a living system to meet constantly

${ }^{20}$ Raymond, L., \& Bergeron, F.: Project management information systems: An empirical study of their impact on project managers and project success. International Journal of Project Management, 26(2), 213-220. https://doi.org/10.1016/j.ijproman.2007.06.002; 2008.

${ }^{21}$ Campanelli, A. S., \& Parreiras, F. S.: Agile methods tailoring - A systematic literature review. Journal of Systems and Software, 110, 85-100, 2015, p. 86.

${ }^{22}$ Moran, A.: Agile Project Management. In: Managing Agile. Springer, Cham., 2015.

${ }^{23}$ Perlak, J.: Characteristics of self-organizing teams in agile project management: A case study, acta universitatis Nicolai copernici, 2019. p. 19-27.

${ }^{24}$ Lenges, M., Kloppenborg, T., Forte, F.: Identifying Key Agile Behaviors That Enhance Traditional Project Management Methodology, Journal of Strategic and Sustainability Vol. 13(2) 2018, p. 23. 
changing market conditions ${ }^{25}$. Organisation becomes a living organism. Characteristics of such lived agility are customer orientation and employee orientation, agility, ability to react and change and resilience ${ }^{26}$.

The use of highly qualified people brings not only technical, but also organisational psychological topics to projects, which are already considered and applied in the agile approach with the defined values and methods. The project manager, a generalist and team developer, can no longer give clear instructions in detail, but acts more as a coordinator of specialists and is responsible for cooperation and communication and hands over responsibilities for planning and ensuring factors to the people who work in the project. Instead of looking for errors in the employees or their qualifications, the agile approach looks at the environment and influencing factors and tries to install changes to the process and structure.

In agile project management, commitment to the team, the project object and the environment is a key success factor. The success and connection generally correlate with the attitude and the job satisfaction of the team members with whom he or she is compared to the project, the team and the environment ${ }^{27}$. Agile project management is based on empirical process and can by defined as a never-ending learning process ${ }^{28}$.

According to Sutherland and Ahmad traditional project management methods are noniterative, sequential, phased, and plan-driven ${ }^{29}$. But author like Joslin \& Müller assumes that it is hierarchical in structure in-addition to these characteristics. Furthermore, traditional project management theorists believe that it is a standardized process since a lot of planning is involved which makes it predictable ${ }^{30}$.

The waterfall method follows a clearly defined time frame, budget, scope which represents three dimensions of the iron triangle. The merits that are put forward for the waterfall model include its simplicity and ease of scheduling in laying out steps for development.

${ }^{25}$ Onag, G.: Agile project management goes beyond software development. Computerworld Hong Kong; Newton 2017, p. 1-3.

${ }^{26}$ Fernandez, D. J., \& Fernandez, J. D.: Agile project management - Agilism versus traditional approaches. Journal of Computer Information Systems, 49(2), 2008.

${ }^{27}$ El-Wakeel, F..: Further Demystification of agile Project Management, Technology Work Book, Strategy Finance/August 2019, p. 79.

${ }^{28}$ Measey, P.: Agile Foundations : Principles, Practices and Frameworks. (Radstad, Ed.). Swindon, SN2 1FA, UK: BCS Learning \& Development Ltd., 2015.

${ }^{29}$ Sutherland, J., \& Ahmad, N.: How a Traditional Project Manager Transforms to Scrum: PMBOK vs. Scrum, (Salt Lake City). https://34slpa7u66f159hfp1fhl9aur1-wpengine. netdna-ssl.com/wp-content/uploads/2014/05/PMBOK-vs.-Scrum-Agile2011.pdf, 2011.

${ }^{30}$ Joslin, R., \& Müller, R.: Relationships between a project management methodology and project success in different project governance contexts. International Journal of Project Management, 33(6), 1377-1392, 2015. 
Formal and informal networks come alongside the hierarchical organisational structure. The networks ensure faster decisions and flexible provision of resources, while the hierarchical structures ensure the necessary stability and implementation standards ${ }^{31}$.

Internal communication provides special communication platforms to promote quick coordination and decision-making within the framework of informal exchange relationship.

When putting together members of a group, the form of collaboration is still important when developing agile teams. Coagulating members conduct their activities relatively independently.

Agile project management is based on self-organised and self-learning teams or individuals. This requires a good network from each team member in the medium term, in which they can acquire and validate their required knowledge and information. In addition to the current situation and cultural influences, the actions of a team member also depend on the values they have and are correlated with each other ${ }^{32}$.

This type of teams will be characterised by having a fast decisionmaking process, high motivational levels due to the sense of autonomy and increased levels of initiative and continuous improvement ${ }^{33}$.

However, there are some factors that can demotivate team members, such as the increased level of stress for certain people due to the higher requirements in visibility and accountability, the continuous need to dedicate time to meetings, and the difficulty related to managing complex tasks in a short time frame.

For this reason, agile project management is being used more and more as it allows to adapt to a constantly changing world. The agile approach offers a flexible and less predictable approach. More and more companies that have developed their products using traditional waterfall methods are switching to agile practices.

In order to be able to react to the change in goals within a project by the client, technological progress or a lack of resources, classic and

${ }^{31}$ Knorre, S.: Interne Unternehmenskommunikation aus der Perspektive organisationaler Resilienz. In G. Bentele, M. Piwinger, \& G. Schönborn (Hrsg.), Kommunikationsmanagement. Strategien, Wissen, Lösungen (Loseblattsammlung, Lieferung 3.90). Neuwied: Luchterhand, 2012, pp. 7-8.

32 Tessem, B.: Individual empowerment of agile and non-agile software developers in small teams. Information and Software Technology, 56, 873-889, 2014.

${ }^{33}$ McHugh, O., Conboy, K., \& Lang, M.: Using Agile Practices to Influence Motivation within IT Project Teams. Scandinavian Journal of Information Systems, 23, 85-110, 2011, p. 98-100. 
planning-oriented project management often turned out to be too rigid and inflexible ${ }^{34}$.

In practice, classic project management models are used for projects that can be planned consistently and that are hardly variable over the course of the project. In the classic project management, the goal, time, and costs are important and those influencing factors can be clearly defined right from the start of the project. In addition, there is an important role in the implementation according to the waterfall model of management policy since the individual teams receive little personal responsibility ${ }^{35}$. Due to the detailed documentation of all phases, this model also favours projects with many external service providers and various interest groups, provided that these were sufficiently included in the development process right from the start in the planning and definition phase ${ }^{36}$.

In agile project management the entire project is not planned right from the start, but rather worked in stages that are characterised by a high degree of communication, adaptability and exchange. The project team undertakes the planning of these stages together and at the end of each stage there should be a result and the stage completed should be assessed in retrospective. This should lead to an increase in quality, acceleration of development time, focus on a result and a constant improvement of the process.

The following illustration (Figure 2) shows the different procedures for common classic and agile procedures.

In the waterfall model, the phases are predefined, and the next phase can only be started after the first phase has been completed. The form of classic project management is based on a linear sequence of individual project phases. This procedure is considered rigid and requires a long planning time. Documentation of the individual phases is particularly important, which ensures transparency of project progress and expenses.

Due to the linearity of the process, classic project management can be implemented in organisational structures with a hierarchical structure with little effort. The subdivision into individual, self-contained phases that do not allow any feedback to previous phases after completion is a special aspect.

${ }^{34}$ Onag, G.: Agile project management goes beyond software development. Computerworld Hong Kong; Newton 2017, p. 1-3.

${ }^{35}$ Lenges M., Kloppenborg T., Forte F: Identifying Key Agile Behaviors That Enhance Traditional Project Management Methodology., Journal of Strategic and Sustainability Vol. 13(2) 2018, p. 23.

${ }^{36}$ Wysocki, R.: Effective Project Management: Traditional, Agile, Extreme. Book (Vol. $7^{\text {th }}$ edition), 2014. 


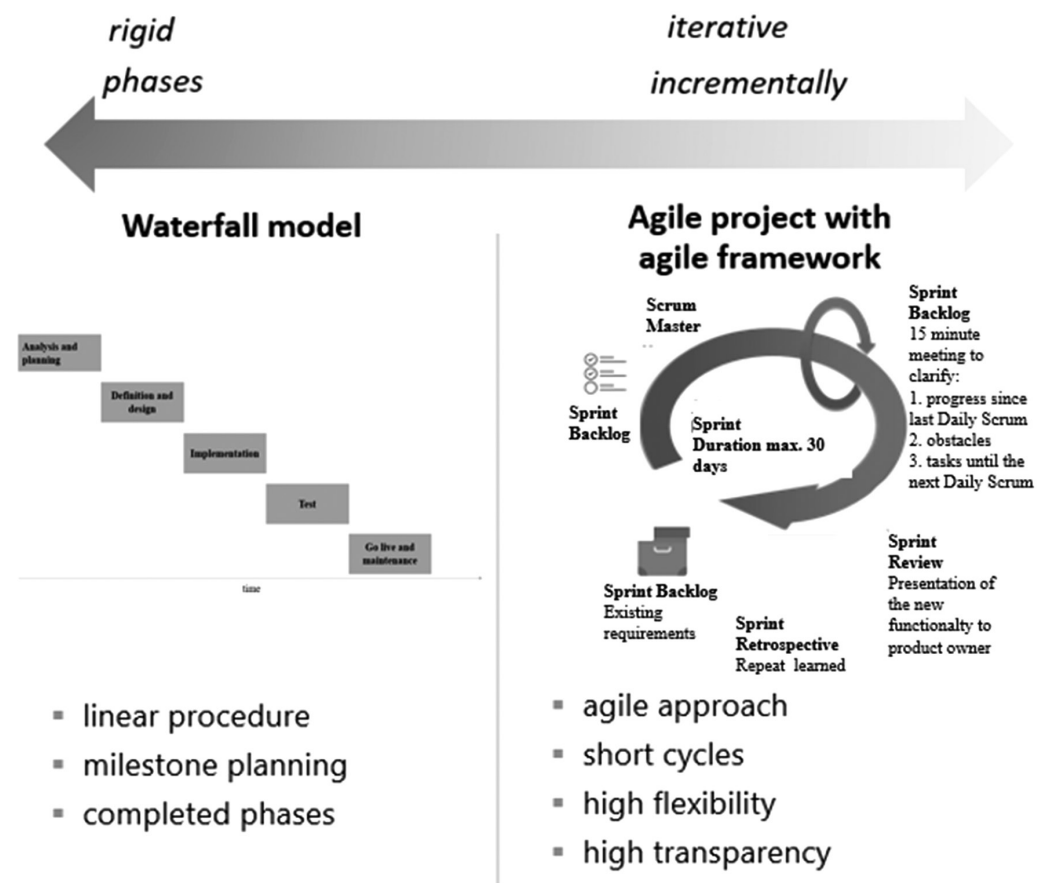

Figure 2. Structural Differences of the Waterfall model and Agile model. Source: Author's illustration

In contrast, the agile approach in projects is contradictory. Work is done in repetitive sprints, in short periods of time, and the result is built on the acquired knowledge ${ }^{37}$. With the agile model there are no rigid phases, but the different stages take place simultaneously and functional products are created and tested in several iterations.

Due to the increasing number of projects and the emergence of complexity, there is a growing need for transparency. The projects are partly in competition with each other. Several people in companies are only responsible for monitoring and control, so that the process is in accordance with the prescribed procedure.

Apart from the importance of project management in general, differentiation in size, uniqueness and complexity of projects put emphasis on the necessity of tailored management methods. Increasingly it is argued that nowadays a pure project management approach (the traditional

${ }^{37}$ El-Wakeel, F. A.: Further Demystification of agile Project Management, Technology Work Book, Strategy Finance/August 2019, p. 80. 
project management approach) is no longer effective ${ }^{38}$. Nevertheless, most of the current project management methodologies still seem to underestimate the influence of the dynamic environment.

\section{The Role of Leadership in the agile change}

Leadership and the agile change are strongly connected. Every change can be successfully integrated if the leadership in all levels enforce and support the agile change in the company. Leaders are able to establish a new agile mindset, work out strategic direction und support by implementation of agile methods in projects.

Leadership is a reciprocal, result-oriented, unstable object of giving and receiving, of expecting and fulfilling. These are always (micro) political processes, because "leadership" stands not just only for neutral psychosocial "soft facts" such as relationships, behaviours, feelings, motivation, climate, shared successes, but for interests, power, counter-power, dependencies, and sovereignty as well ${ }^{39}$.

In the leadership concept of leadership, organisations with a high need for change are assigned a leadership style that is endowed with a transformational characteristic. It is particularly appropriate in situations in which leaders cannot assess the work or solution approaches of their employees in detail, for example due to specialist knowledge or also in the context of quick decision-making.

According to Kotter effective manager is about giving employees an understanding of why a change process is necessary and what organisational benefits are derived from $\mathrm{it}^{40}$. So that everyone understands why certain processes are being carried out, just as complex as a change process. The change process is now a constant condition of companies, but employees do not understand the change and are therefore not behind it.

Studies by Jantz 2012, highlighted transformational leadership, which it was found to be more effective than laissez-faire or transactional leadership ${ }^{41,42}$.

${ }^{38}$ Hertogh, M., \& Westerveld, E: Playing with Complexity. Management and organisation of large infrastructural projects: AT Osborne/Transumo, 2010.

${ }^{39}$ Rieckmann, H.: Führungskraft und Management Development. München: GerlingAkad.-Verl, 2000.

${ }^{40}$ Kotter, J. P., \& Cohen, D. S.: The heart of change: real-life stories of how people change their organizations. Boston, MA: Harvard Business School Press, 2002.

${ }^{41}$ Castiglione, J.: Organizational learning and transformational leadership in the library environment. Library Management, 27(4/5), 289-299, 2006.

42 Jantz, R. C.: Innovation in academic libraries: An analysis of university librarians' perspectives. Library \& Information Science Research, 34(1), 3-12, 2012. 
Bass believes that the actions of transformational leaders focus more on organisational interests and put their own interests in the background. The transformative leader is respectful, confident, is clear in acting and thinking and also clearly communicates the goals. He or she involves employees and supports the innovation process or the willingness to try new things. This type of leader does not forget to support the learning and development process of the employee ${ }^{43}$.

According to Kouzes \& Posner 2012, the transformational leader achieves the highest level of performance and variation in the change process by interweaving the 4 levels ${ }^{44}$, by means of four dimensions:

1. Idealised influence

2. Inspirational motivation

3. Intellectual stimulation and

4. Individualised consideration

According to Mellor, leadership is characterised by trust and relies on the common achievement of the leader and the leader with a generally altruistic understanding of how to act. Leadership culture is going through a progressively rapid change.

This integrative understanding is already in the traditional concept of transformational leadership. It also requires leadership communication that is professionally designed from a strategic and operational point of view. In the context of agility, however, a new strong frame of reference for the consideration of leadership communication emerges as part of the expanded, transformational leadership style, which deals with the communication of "resilience".

Not only the transformational leader, but also the servant leader can lead the organisation and the team through the change process.

Overstreet et al. further explained that "elements of servant leadership theory and social exchange theory explain in what way developing organisational commitment via servant leadership behaviours can ultimately impact performance" 45

According to Greenleaf, "The servant-leader is servant first, it begins with the natural feeling that one wants to serve, to serve first. Then

${ }^{43}$ Bass, B. M.: From transactional to transformational leadership: Learning to share the vision. Organizational Dynamics, 18(3), 19-31, 1990.

${ }^{44}$ Yukl, G. A.: Leadership in organizations ( $8^{\text {th }}$ ed.). England: Pearson Education, Limited, 2013.

${ }^{45}$ Overstreet, R. E., Hazen, B. T., Skipper, J. B., \& Hanna, J. B.: Bridging the gap between strategy and performance: Using leadership style to enable structural elements. Journal of Business Logistics, 35 (2), 136-149, 2014, p. 136. 
conscious choice brings one to aspire to lead." ${ }^{46}$ The servant leader builds on trust and a commitment in an organisation. The servant leader aims to motivate employees and the servant leader also aims to develop employees. Above all, it is about personal and professional development as the exclusive achievement of his or her goals ${ }^{47}$.

The leadership theories that underlay the study also encompass theories of transformational leadership and servant leadership as important components of support in changing and shaping organisational culture.

The servant Leader offers a new approach to being a leader, one that is not classically seen in front. The servant leader is understood more as a servant who stands behind his or her employees, lets them be creative and let them free working spaces. The servant leader is increasingly appearing in the start-up culture and in the IT areas of traditional companies. Where creativity is increasingly required, it is controversial to think and act hierarchically and task-oriented. But it is precisely this leadership type that would be an opportunity for renewal in the big companies.

Companies educate and train their leaders to develop coaching skills and to have it like a leader's toolkit. But this mean that not every leader passes the adaptation of skills in the position. So, after the training it is a common way to fall to the common und usual command and control leadership way. So in summary the change process can 't happen really fast.

In order to be able to change it is necessary to inspire as a leadership employee and above all communication is crucial. To explain and communicate the goals, as well as the processes is crucial for changing culture.

It is important to give employees a certain amount of freedom and to promote self-organization. It is not always a smooth process to switch to self-organisation, where groups take ownership of their own decisions. Employees also need to be open to the type of change and see selforganisation as an advantage. Working according to instructions seems to be a better alternative because not every employee is ready for the type of change.

The following illustration (Figure 3) shows the rough structure of leadership influence and dependencies on the organizational performance.

${ }^{46}$ Greenleaf, R. K.: Servant Leadership: A journey into the nature of legitimate power and greatness. Mahwah, NJ: Paulist Press, 1977.

${ }^{47}$ Liden, E. C., Wayne S. Y., Thao H., Henderson D.: Servant Leadership: Development of a multidimensional measure and multilevel assessment. The Leadership Quarterly, Volume 19, Issue 2, 2008, p. 161-177. 


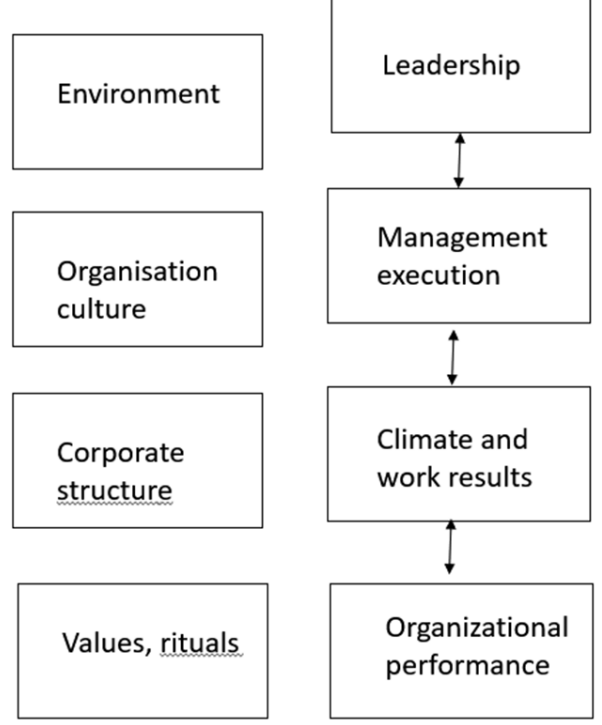

Figure 3. Leadership influence and dependencies on the organizational performance

Source: Author`s illustration

The above illustration shows that the levels are interrelated. The organisational performance depends very much on the results, which in turn are shaped and carried out by the leader.

The employees view the agile change process either positively or negatively. It depends on how leadership interaction works. If the employees understand what exactly happens in the change process and the complex change process brings an advantage to people and the organisation, then there is also the belief that the change process is necessary. In case of ignorance or not involving the employees there will be more resistance to the change process and disrupts organisational identity.

The following outline (Figure 4) shows the interdependency of the agile principle with leaders, culture and communication, employees and goals and visions of the company.

The illustration above shows how the agile principles interact with the following factors, such as employees, leaders, vision and aims and culture \& communication, and are interdependent to a certain extent. The elements are also dependent on each other and represent a kind of interaction. 


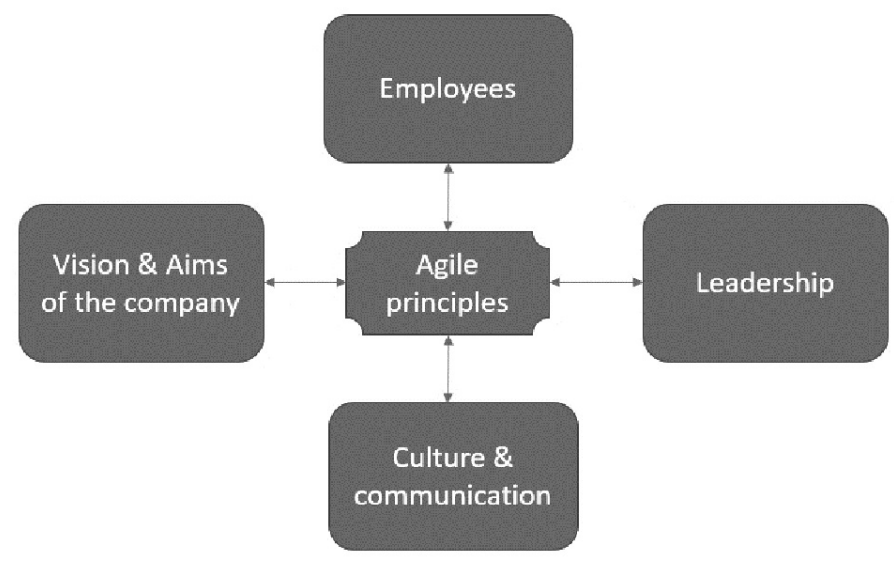

Figure 4. Interaction of the influencing corporate elements to create agile principles

Source: Author's illustration

It is a long and ongoing process until an agile way of thinking and working is reflected in companies. The results show that a stable framework inside the organization is crucial for this ${ }^{48}$.

Paradoxically, this leads to the fact that the basic rules and meaningful elements are ultimately subject to a negotiation process. That is, they themselves are to be regarded as contingent, but not to the extent that, for example, business strategic decisions are. The conscious acceptance, even the targeted use of paradoxes in leadership behaviour is generally seen as promoting agility ${ }^{49}$.

Planning is also key for team changes and employee development. In fact, employees need to be part of redefining quality of services and products, or companies will be unsuccessful in meeting change objectives. Accordingly, the basic elements of agile leadership are characterised on the one hand by a high degree of content-based and action-guiding basic rules - for all hierarchical and heterarchical organizational units. On the other hand, agile company management is based on independent, self-responsible action and collaboration among network members.

In a common change process, there are many ambiguities for the leadership especially at the beginning when no fundamental, systematic decisions

${ }^{48}$ Redmann, B.: Agiles Arbeiten im Unternehmen. Rechtliche Rahmenbedingungen und gesetzliche Anforderungen. Freiburg: Haufe, 2017, p. $34 \mathrm{ff}$.

${ }^{49}$ Lewis, M. W., Andriopoulos, C., \& Smith, W. K.: Paradoxical leadership to enable strategic agility. California Management Review, 2014, p. $63 \mathrm{f}$. 
or changes are in place and implementation are not yet mature. Leaders question how leadership should look like under these circumstances and try to transfer the changes into their praxis. Uncertainties and identity difficulties often arise.

\section{Conclusion}

Companies are in the age of changing market conditions and unpredictability due to rapid changes. The changing market conditions are currently being triggered by digital progress in order to tap to the new opportunities for a market change.

Today in companies, employee expect a leader who brings through the change and during this change generate a creative effect. The VUCA world probably has the greatest creative influence because predictability is hardly possible.

Agile change has visible and invisible processes that are in change. With agile adoption the change of company processes may be the most difficult.

The change process in companies aims to integrate the values or characteristics of agility into the company. The companies should therefore become more sensitive to signals from their environment and be able to react proactively and flexibly to them in the future. For this, however, not only teams and structures must be revised, but also the agile mindset and methods must be internalised.

Leadership has a strong influence on employee performance and thus ultimately on team performance. Especially in an agile working environment the implementation of good leadership is fundamental. The challenge: The leader's understanding of their role in an agile context changes completely. Up to now, management responsibilities have been centralised, but in an agile context, management responsibilities are distributed to other roles that did not exist in this form before. The responsibilities are shifted to where the expertise is to be find: to the employees. The focus is on the employee as a specialist. This change allows companies to do away with lengthy decision-making processes and coordination loops across several hierarchies and to achieve high flexibility and dynamic adaptation. However there is a determination about an ongoing process here.

In summary it is recommended to analyse and define the term agile for the company individually before planning und starting with implementation of agile methods. Changes can only be successfully implemented if employees and leaders are also willing to change. Changes, including the use of agile methods in the company, require the ability to learn - both on the part of employees and managers and on the part of the organisation. In this case, the leader must exemplify the willingness to change. 


\section{REFERENCES}

1. Alegría and Bastarrica (2006, pp. 5-10); Häusling, A., \& Wiegand, S. (2012, p. 19), Agil dank Scrum In Personalmagazin, 06, 18-20.

2. Bass, B. M. (1990): From transactional to transformational leadership: Learning to share the vision. Organizational Dynamics, 18(3), 19-31.

3. Campanelli, A. S., \& Parreiras, F. S.: Agile methods tailoring - A systematic literature review. Journal of Systems and Software, 110, 85-100. 2015.

4. Castiglione, J. (2006): Organizational learning and transformational leadership in the library environment. Library Management, 27(4/5), 289-299.

5. Greenleaf, R. K. (1977): Servant Leadership: A journey into the nature of legitimate power and greatness. Mahwah, NJ: Paulist Press.

6. Dingsøyr, T., \& Lassenius, C. (2012): Emerging themes in agile software development: Introduction to the special section on continuous value delivery. Information and Software Technology.

7. El-Wakeel F. (2019): Further Demystification of agile Project Management, Technology Work Book, Strategy Finance/August.

8. Erretkamps, H., \& Oswald, A. (2014): Der agile Produktentstehungsprozess - mehr als ein Prozess. In R. Wagner, \& N. Grau (Eds.), Basiswissen Projektmanagement Prozesse und Vorgehensmodelle, Düsseldorf: Sypmposion.

9. Fernandez, D. J., \& Fernandez, J. D. (2008): Agile project management - Agilism versus traditional approaches. Journal of Computer Information Systems, 49(2).

10. Förster, K., \& Wendler, R. (2012): Theorien und Konzepte zu Agilität in Organisationen. Dresdner Beiträge zur Wirtschaftsinformatik, 63(12)., 1.

11. Häusling, A., Rutz, B., Oimann, K., \& Oebbeke, B. (2014): Agil anpassen! Personalmagazin.

12. Hertogh, M., \& Westerveld, E (2010): Playing with Complexity. Management and organisation of large infrastructural projects: AT Osborne/Transumo.

13. Highsmith, J. A. (2004): Agile project management; creating innovative products; 1.Auflage; Addison-Wesley Longman; Amsterdam.

14. Jantz, R. C. (2012): Innovation in academic libraries: An analysis of university librarians' perspectives. Library \& Information Science Research, 34(1), 3-12.

15. Joslin, R., \& Müller, R. (2015): Relationships between a project management methodology and project success in different project governance contexts. International Journal of Project Management, 33(6), 1377-1392.

16. Kotter, J. P., \& Cohen, D. S. ( 2002): The heart of change: real-life stories of how people change their organizations. Boston, MA: Harvard Business School Press.

17. Knorre, S. (2012): Interne Unternehmenskommunikation aus der Perspektive organisationaler Resilienz. In G. Bentele, M. Piwinger, \& G. Schönborn (Hrsg.), Kommunikationsmanagement. Strategien, Wissen, Lösungen (Loseblattsammlung, Lieferung 3.90). Neuwied: Luchterhand.

18. Lenges M., Kloppenborg T., Forte F. (2018): Identifying Key Agile Behaviors That Enhance Traditional Project Management Methodology, Journal of Strategic and Sustainability Vol. 13(2). 
19. Lewis, M. W., Andriopoulos, C., \& Smith, W. K. (2014): Paradoxical leadership to enable strategic agility. California Management Review.

20. Liden, E. C., Wayne S. Y., Thao H., Henderson D. (2008): Servant Leadership: Development of a multidimensional measure and multilevel assessment. The Leadership Quarterly, Volume 19, Issue 2.

21. Onag G. (2017): Agile project management goes beyond software development. Computerworld Hong Kong; Newton.

22. Overstreet, R. E., Hazen, B. T., Skipper, J. B., \& Hanna, J. B. (2014): Bridging the gap between strategy and performance: Using leadership style to enable structural elements. Journal of Business Logistics, 35 (2), 136-149.

23. Perlak J. (2019): Characteristics of self-organizing teams in agile project management: A case study, acta universitatis Nicolai copernici.

24. McHugh, O., Conboy, K., \& Lang, M. (2011): Using Agile Practices to Influence Motivation within IT Project Teams. Scandinavian Journal of Information Systems, 23, 85-110.

25. Measey, P.: Agile Foundations (2015): Principles, Practices and Frameworks. (Radstad, Ed.). Swindon, SN2 1FA, UK: BCS Learning \& Development Ltd.

26. Mergel, I. (2016): Agile Innovation management in government: A research agenda. Government Information Quarterly, 33(3).

27. Miller, G. G. (2001): TOOLS '01 Proceedings of the $39^{\text {th }}$ International Conference and Exhibition on Technology of Object-Oriented Languages and Systems: The Characteristics of Agile Software Processes (pp. 385-387). Washington, DC.

28. Moran A. (2015): Agile Project Management. In: Managing Agile. Springer, Cham.

29. Raymond, L., \& Bergeron, F. (2008): Project management information systems: An empirical study of their impact on project managers and project success. International Journal of Project Management, 26(2), 213-220. https://doi. org/10.1016/j.ijproman.2007.06.002.

30. Redmann, B. (2017): Agiles Arbeiten im Unternehmen. Rechtliche Rahmenbedingungen und gesetzliche Anforderungen. Freiburg: Haufe.

31. Rigby, D. K., Sutherland, J., \& Takeuchi, H. (2016). Embracing Agile. Harvard Business Review.

32. Rieckmann, H. (2000): Führungskraft und Management Development. München: Gerling-Akad.-Verl,

33. Roghé F., Scholz S., Schudey A. (04/2017): Organisation im 21. Jahrhundert. Eine Studie identifiziert sechs Erfolgsfaktoren. Zeitschrift Führung und Organisation. www.wiso-net.de. (86. Jg.).

34. Siakas, K. V., \& Siakas, R. (2012): The Agile Professional Culture: A Source of Agile Quality. Software Process Improvement and Practice, 12.

35. Stoffel, M. 2016: Leadership 4.0 - Unternehmen brauchen ein neues "Betriebssystem”. In von C. Au (Ed.), Wirksame und nachhaltige Führungsansätze (pp. 205-222), Wiesbaden:Springer.

36. Sutherland Jeff, \& Ahmad Nafis. (2011): How a Traditional Project Manager Transforms to Scrum: PMBOK vs. Scrum, (Salt Lake City). https://34slpa7u66f159 hfp1fhl9aur1-wpengine.netdna-ssl.com/wp-content/uploads/2014/05/PMBOK-vs.Scrum-Agile2011.pdf. 
37. Termer F., Nissen V. (2014): Zum Begriff der Agilität - Betrachtungen und Implikation ausetymologischer Perspektive.

38. Tessem, B. (2014): Individual empowerment of agile and non-agile software developers in small teams. Information and Software Technology, 56, 873-889.

39. Williams, L., \& Cockburn, A. (2003): Agile Software Development: It's about Feedback and Change. Computer, 36(6), 39-43.

40. Wysocki, R. (2014): Effective Project Management: Traditional, Agile, Extreme. Book (Vol. $7^{\text {th }}$ editio).

41. Yukl, G. A. (2013): Leadership in organizations ( $8^{\text {th }}$ ed.). England: Pearson Education, Limited. 